\title{
Lead-dependent infective endocarditis and pocket infection - similarities and differences
}

\section{Odelektrodowe zapalenie wsierdzia i miejscowa infekcja loży generatora - podobieństwa i różnice}

\author{
Anna Polewczyk ${ }^{1,2}$, Agnieszka Kędra-Banasik ${ }^{3}$, Aneta Polewczyk ${ }^{4}$, Rafał Podlaski ${ }^{5}$, Marianna Janion $^{1,2}$, \\ Andrzej Kutarski ${ }^{6}$ \\ ${ }^{1}$ Department of Internal Diseases, Cardiology and Medicine Nursing, Institute of Nursing and Obstetrics, Faculty of Medicine \\ and Health Sciences, Jan Kochanowski University, Kielce, Poland \\ Head of the Department: Prof. Marianna Janion MD, PhD \\ ${ }^{2}$ Second Department of Cardiology, Świętokrzyskie Cardiology Center, Kielce, Poland \\ Head of the Department: Prof. Marianna Janion MD, PhD \\ ${ }^{3}$ Deparment of Cardiology, Regional Specialist Hospital of S. Lucas, Końskie, Poland \\ Head of the Department: Dr Marian Sierant \\ ${ }^{4}$ Provincial Hospital, Kielce, Poland \\ Head of the Department: Prof. Marianna Janion MD, PhD \\ ${ }^{5}$ Institute of Biology, Jan Kochanowski University, Kielce, Poland \\ Head of the Department: Grażyna Świderska-Kołacz MD, PhD \\ ${ }^{6}$ Department of Cardiology, Medical University of Lublin, Lublin, Poland \\ Head of the Department: Prof. Andrzej Wysokiński MD, PhD
}

Key words: lead-dependent infective endocarditis, pocket infection, abrasion of the leads, vegetations.

Słowa kluczowe: odelektrodowe zapalenie wsierdzia, infekcja loży, wewnątrzsercowe przetarcie elektrod, wegetacje.

\begin{abstract}
Introduction: Infectious complications in patients with implanted pacemakers are divided into infections of the generator pocket (PI) and lead-dependent infective endocarditis (LDIE).

Aim of the research: Identification of risk factors for developing different types of infections and evaluation of the extent of infectious complications.

Material and methods: We compared two groups of patients with infectious complications, who underwent transvenous lead extraction (TLE) in the Reference Centre between March 2006 and July 2013. The groups consisted of 414 patients with LDIE and 205 with PI. We analysed risk factors, clinical manifestations, inflammatory markers, microbiology, and echocardiography results.

Results: The coexistence of LDIE and PI was observed in $62.1 \%$ patients. There were no significant differences in the presence of host-dependent risk factors. Patients with LDIE significantly more frequently had abrasion of leads (35.1.\% vs. 21.0\%; $p=0.0001)$ connected with other procedural risk factors: a larger number of the leads (2.2 vs. $2.0 ; p=0.004)$ lead loops $(24.6 \%$ vs. $13.2 \% ; p=0.001)$, and longer time interval from the last procedure prior to TLE ( 28.7 vs. 22.6 months; $p=0.005)$. Fever and pulmonary infections, higher level of erythrocyte sedimentation rate, C-reactive protein, procalcitonin, vegetation presence, and higher pulmonary systolic pressure were also revealed in patients with LDIE. Positive blood and leads culture were observed in $34.5 \%$ and $46.4 \%$ patients with LDIE.

Conclusions: The frequent coexistence of LDIE and PI confirms their common pathogenesis, but the phenomenon of abrasion suggests also another mechanism for the development of LDIE. Intensity of clinical syndromes, high inflammatory parameters, echocardiography, and microbiology findings are helpful in assessment of the extensity of the infection.
\end{abstract}

\section{Streszczenie}

Wprowadzenie: Podział powikłań infekcyjnych u pacjentów z implantowanymi urządzeniami do stałej stymulacji serca obejmuje infekcje miejscowe loży generatora (PI) oraz odelektrodowe zapalenie wsierdzia (LDIE).

Cel pracy: Porównanie czynników ryzyka rozwoju poszczególnych typów infekcji oraz ocena stopnia rozprzestrzenienia powikłań infekcyjnych. 
Materiał i metody: Przeprowadzono analizę porównawczą dwóch grup chorych: 414 pacjentów z LDIE oraz 205 z PI poddawanych zabiegom przezżylnego usunięcia elektrod wewnątrzsercowych (TLE) w okresie od marca 2006 do lipca $2013 \mathrm{r}$. w ośrodku referencyjnym TLE. Analizie poddano czynniki ryzyka wystąpienia powikłań infekcyjnych, obraz kliniczny poszczególnych form infekcji, wartości parametrów zapalnych, wyniki badań mikrobiologicznych oraz echokardiograficznych.

Wyniki: Współistnienie LDIE i PI stwierdzono u 62,1\% chorych. Pomiędzy grupami nie obserwowano istotnych różnic w występowaniu czynników ryzyka zależnych od gospodarza. U pacjentów z LDIE najczęściej występowało zjawisko wewnątrzsercowego przetarcia elektrod $(35,1 \%$ vs $21,0 \% ; p=0,0001)$ związane z istotnie częstszym występowaniem czynników proceduralnych: większej liczby elektrod (2,2 vs 2,0; $p=0,004)$, obecnością pętli $(24,6 \%$ vs $13,2 \% ; p=0,001)$ oraz dłuższego czasu od poprzedzającego zabiegu $(28,7$ vs 22,6 miesiąca; $p=0,005)$. W grupie LDIE stwierdzono wyższy odsetek stanów gorączkowych i infekcji płucnych, wyższy poziom OB, białka C-reaktywnego i prokalcytoniny, częstszą obecność wegetacji oraz wyższe wartości ciśnienia w tętnicy płucnej. Posiewy krwi i elektrod były dodatnie, odpowiednio u 34,5\% i 46,4\% pacjentów z LDIE.

Wnioski: Częste współistnienie LDIE z PI potwierdza wspólną patogenezę obu chorób, jednak zjawisko wewnątrzsercowego przetarcia elektrod częściej obserwowane w grupie LDIE sugeruje także inny patomechanizm rozprzestrzeniania infekcji. Nasilenie objawów klinicznych, wartości parametrów zapalnych, badania echokardiograficzne oraz posiewy bakteryjne są pomocne w ocenie rozległości infekcji.

\section{Introduction}

Infectious complications in patients with permanent pacemakers are an important clinical problem. Available evidence shows rapidly increasing rates of cardiac device infections (CDI) in relation to the number of implantations $[1,2]$. According to American data from 1990-1999 the rate of implantations increased by $42 \%$ whereas the rate of infectious complications increased by $124 \%$ in this population of patients [2, 3]. Another analysis of data from 1993-2008 revealed an increase in CDI by as much as $210 \%$, the increase being significant in recent years: from $1.53 \%$ in 2004 to $2.41 \%$ in 2008 ( $p<0.001)$ [4]. It is difficult to provide the exact occurrence of CDI due to vagueness of terminology. The term CDI does not exclude from analysis patients with mechanical valves or percutaneous closure of septal defects, patients with stents and intravascular catheters, as well as patients with implantable left ventricular assist devices. Another problem is precise classification of infectious complications occurring exclusively in patients with cardiovascular implantable electronic devices (permanent pacemakers PM, implantable cardioverter-defibrillators - ICD, and cardiac resynchronization therapy devices - CRT). It is also difficult to estimate the spread of infection in the presence of pocket infection (PI). A common mechanism by which lead-dependent infective endocarditis and pocket infection develop seems obvious; however, it is important to take into account the presence of isolated PI, and especially isolated lead-dependent infective endocarditis (LDIE) with a different pathological mechanism of development. Generally, an assessment of the extensity of the infectious process is of major importance when making therapeutic decisions.

\section{Aim of the research}

The aim of the study was to assess the risk factors for developing different types of infections and evaluation of the extent of infectious complications.

\section{Material and methods}

In a population of 1426 subjects directed to transvenous lead extraction (TLE) in the Reference Clinical Cardiology Centre in Lublin (Poland) between March 2006 and July 2013 a group of 619 patients (43.4\%) with infectious complications was selected for analysis. The 619 patients were divided into two groups: with LDIE - 414 (66.9\%) patients and with PI - 205 (33.1\%) patients. The diagnosis of LDIE was made according to modified Duke lead criteria taking into account major clinical criteria of lead-dependent infective endocarditis: pocket infection and pulmonary embolism as well as the presence of vegetations and positive blood culture. According to the ESC guidelines definite infective endocarditis is diagnosed if two major or one major plus three minor or five minor criteria were met. Patients with probable LDIE, i.e. meeting one major plus one minor or three minor criteria, were also included in the analysis [5]. The patients with LDIE and PI were compared for host-dependent risk factors such as age, gender, diabetes mellitus, renal failure, mechanical heart valves, chronic antiplatelet therapy, and oral anticoagulation, and for procedure-related risk factors such as the number of leads, lead dwell time, type of intracardiac device, the presence of loops and abandoned leads, and abrasion of endocardial leads. The two groups were also analysed for the presence of clinical symptoms: fever, shivering, lung infections, previous antibiotic therapy, and laboratory results: white blood cell count (WBC), erythrocyte sedimentation rate (ESR), C-reactive protein (CRP) and procalcitonin, microbiological tests, echocardiographic parameters such as vegetations, left ventricular ejection fraction (EF), left ventricular diastolic diameter (LVDD), and pulmonary artery systolic pressure (PASP). Additionally, multivariate analysis of risk factors was performed to estimate the probability of LDIE. 


\section{Statistical analysis}

Continuous variables were expressed as mean \pm standard deviation. Student's $t$-test was used to test for the significance of differences between the means. Qualitative variables were compared with a $\chi^{2}$ test. The two-sided $p$-value $<0.05$ was considered significant. The statistics were calculated using Statistica version 10. Multivariate analysis was carried out to study the relationships between an explained (dependent) variable and many explanatory (independent) variables. Explanatory variables were identified using the Wald test, whereas collinearity was checked using the variance inflation factor (VIF).

\section{Results}

\section{Comparative analysis of risk factors and clinical parameters in patients with LDIE and PI}

Patients with LDIE were younger than patients with PI. The frequency of patient-dependent risk factors such as diabetes mellitus, renal failure, prior implantation of an artificial heart valve, antiplatelet therapy, and chronic anticoagulation was similar in the two patient groups.

Of procedure-related risk factors, a larger number of implanted leads was detected in patients with isolated LDIE. Additionally, patients with LDIE had more lead loops, and the most frequent abrasion of endocardial leads. Similarly, the time interval from the last procedure prior to TLE to the onset of infection was longer in this group of patients (Table 1).

\section{Comparative analysis of clinical}

manifestations in patients with isolated LDIE, isolated PI, and with LDIE + PI

Of clinical manifestations, fever and lung infections were most frequently seen in patients with LDIE as compared with the PI group (55.1\% vs. $14.3 \%$; $p=0.0001$ and $24.9 \%$ vs. $3.1 \%$; $p=0.0001$ ).

Of inflammatory markers, ESR, CRP, and procalcitonin were significantly higher in patients with LDIE than in the PI group (respectively: 43.0 vs. $30.2 \mathrm{~mm}$ in $1 \mathrm{~h} ; p=0.0001 ; 55.9$ vs. $19.6 \mathrm{mg} / \mathrm{dl} ; p=0.008 ; 1.6$ vs. $0.2, p=0.0001)$.

Positive blood cultures were found in $34.5 \%$ of patients with LDIE, and positive cultures of explanted lead

Table 1. Comparison of patient-dependent and procedure-related risk factors in patients with isolated LDIE, isolated PI, and with LDIE + PI

\begin{tabular}{|c|c|c|c|c|}
\hline \multirow{2}{*}{\multicolumn{2}{|c|}{ Parameter }} & LDIE & $\mathrm{PI}$ & \multirow{2}{*}{$\begin{array}{l}\text { Value } \\
\text { of } p\end{array}$} \\
\hline & & & & \\
\hline \multicolumn{2}{|c|}{ Age, mean \pm SD [years] } & $67.3 \pm 14.2$ & $69.5 \pm 13.3$ & 0.064 \\
\hline Gender & Males & $284(68.6 \%)$ & $150(73.2 \%)$ & 0.23 \\
\hline \multirow{5}{*}{$\begin{array}{l}\text { Patient- } \\
\text { dependent } \\
\text { risk factors: }\end{array}$} & Type 2 diabetes mellitus & $92(22.7 \%)$ & $40(19.5 \%)$ & 0.44 \\
\hline & Chronic renal failure (creatinine $>2 \mathrm{~g} / \mathrm{dl}$ ) & $20(4.9 \%)$ & $7(3.5 \%)$ & 0.42 \\
\hline & Mechanical cardiac valve & $22(5.3 \%)$ & $14(6.8 \%)$ & 0.45 \\
\hline & Antiplatelet therapy & $162(39.1 \%)$ & $79(39.0 \%)$ & 0.87 \\
\hline & Oral anticoagulants & $105(25.4 \%)$ & $65(31.7 \%)$ & 0.10 \\
\hline \multirow[t]{9}{*}{$\begin{array}{l}\text { Procedure-related } \\
\text { risk factors: }\end{array}$} & $\begin{array}{c}\text { Number of intracardiac leads prior } \\
\text { to TLE, mean } \pm \text { SD }\end{array}$ & $2.2 \pm 0.8$ & $2.0 \pm 0.8$ & 0.004 \\
\hline & Intracardiac device with ICD lead & $87(21.0 \%)$ & $46(22.4 \%)$ & 0.66 \\
\hline & Intracardiac device with CS lead & $78(18.8 \%)$ & $27(13.2 \%)$ & 0.08 \\
\hline & Number of inactive leads & $0.3 \pm 0.7$ & $0.3 \pm 0.6$ & 1.00 \\
\hline & Lead loops & $102(24.6 \%)$ & $27(13.2 \%)$ & 0.001 \\
\hline & $\begin{array}{c}\text { Number of procedures prior to TLE (including } \\
\text { device implantation) }\end{array}$ & $2.3 \pm 1.4$ & $2.1 \pm 1.1$ & 0.07 \\
\hline & $\begin{array}{l}\text { Time interval from the last procedure prior to } \\
\text { TLE, mean } \pm \text { SD [months] }\end{array}$ & $28.7 \pm 26.5$ & $22.6 \pm 23.1$ & 0.005 \\
\hline & Dwell time, mean $\pm \mathrm{SD}$ & $82.3 \pm 60.6$ & $73.0 \pm 56.4$ & 0.067 \\
\hline & Abrasion of intracardiac leads (\%) & $145(35.1 \%)$ & $41(21.0 \%)$ & 0.001 \\
\hline
\end{tabular}


Table 2. Comparison of clinical manifestations in patients with isolated LDIE, isolated PI, and with LDIE + PI

\begin{tabular}{|c|c|c|c|c|}
\hline \multirow[t]{2}{*}{ Parameter } & & LDIE & $\mathrm{PI}$ & \multirow{2}{*}{$\begin{array}{l}\text { Value } \\
\text { of } p\end{array}$} \\
\hline & & $N=414(66.9 \%)$ & $N=205(33.1 \%)$ & \\
\hline \multirow[t]{3}{*}{ Symptoms: } & Fever. shivering & $228(55.1 \%)$ & $28(14.3 \%)$ & 0.0001 \\
\hline & Lung infections & $103(24.9 \%)$ & $6(3.1 \%)$ & 0.0001 \\
\hline & Previous antibiotic therapy & $316(76.3 \%)$ & $121(59.0 \%)$ & 0.001 \\
\hline \multirow{6}{*}{$\begin{array}{l}\text { Laboratory } \\
\text { tests: }\end{array}$} & WBC $(/ \mu \mathrm{l})$, mean \pm SD & $9616 \pm 5198$ & $8929 \pm 8964$ & 0.23 \\
\hline & ESR after $1 \mathrm{~h}[\mathrm{~mm}]$ & $43.0 \pm 29.7$ & $30.2 \pm 22.2$ & 0.0001 \\
\hline & CRP $[\mathrm{mg} / \mathrm{dl}]$ & $63.6 \pm 71.3$ & $19.6 \pm 30.8$ & 0.0001 \\
\hline & Procalcitonin [pg/ml] & $1.6 \pm 4.4$ & $0.2 \pm 0.3$ & 0.0001 \\
\hline & Positive blood culture & $143(34.5 \%)$ & $0(0.0 \%)$ & 0.0001 \\
\hline & Positive culture of lead segments & $192(46.4 \%)$ & $3(1.5 \%)$ & 0.0001 \\
\hline \multirow[t]{4}{*}{ Echocardiography: } & Vegetations & $280(67.6 \%)$ & $0(0.0 \%)$ & 0.0001 \\
\hline & $\mathrm{EF}$, mean $\pm \mathrm{SD}(\%)$ & $50.4 \pm 14.2$ & $48.7 \pm 14.7$ & 0.17 \\
\hline & LVDD [mm] & $53.9 \pm 10.2$ & $55.2 \pm 10.1$ & 0.13 \\
\hline & PASP $[\mathrm{mm} \mathrm{Hg}]$ & $32.5 \pm 17.1$ & $29.7 \pm 15.7$ & 0.049 \\
\hline
\end{tabular}

Table 3. Results of generalised linear model (GLM), showing the best set of explanatory variables, using binomial distribution with logit-link function

\begin{tabular}{|lcccc|}
\hline Variable & Estimate & SE & Wald statistic $z$ & Value of $p$ \\
Intercept & -1.0277 & 0.3621 & -2.838 & 0.0045 \\
$\begin{array}{l}\text { Number of leads } \\
\text { (2 leads) }\end{array}$ & 0.6303 & 0.2704 & 2.331 & 0.0197 \\
$\begin{array}{l}\text { Number of leads } \\
\text { (3 leads) }\end{array}$ & 0.4228 & 0.4361 & 0.969 & 0.3324 \\
$\begin{array}{l}\text { Number of procedures (2 procedures) } \\
\text { Number of procedures (3 procedures) }\end{array}$ & -0.0812 & 0.2872 & -0.283 & 0.7773 \\
Number of procedures (4 procedures) & 0.8370 & 0.3746 & 2.234 & 0.0255 \\
Duration since the last procedure & 0.3795 & 0.4118 & 0.922 & 0.3568 \\
Fever and shivering & 0.0145 & 0.0052 & 2.799 & 0.0051 \\
Lung infections & 1.7532 & 0.3020 & 5.806 & $<0.0001$ \\
CRP & 1.1961 & 0.5167 & 2.315 & 0.0206 \\
\hline
\end{tabular}

segments in $46.4 \%$ of LDIE patients. On echocardiography vegetations were detected in $67.6 \%$ of patients with LDIE. LVDD and EF were similar in these two groups, whereas PASP was higher in patients with LDIE than in those with PI (32.5 vs. 29.7; $p=0.049$ ) (Table 2).

\section{Multivariate analysis of risk factors for} the development of isolated LDIE (Table 3)

Multivariate analysis showed a significant relationship between possible LDIE and the following risk factors:
- A larger number of leads in a given patient: two leads increased the probability of LDIE by about $88 \%$, and at least three leads by about $53 \%$ as compared with one lead (Figure 1).

- A larger number of procedures prior to TLE: three and four procedures increased the probability of LDIE by about 2.3 and 1.5 times as compared with one procedure.

- An $8 \%$ decrease in the probability of LDIE in patients with two procedures was observed - this meant that the total result was not significant $(p=0.07)$ (Figure 2). 


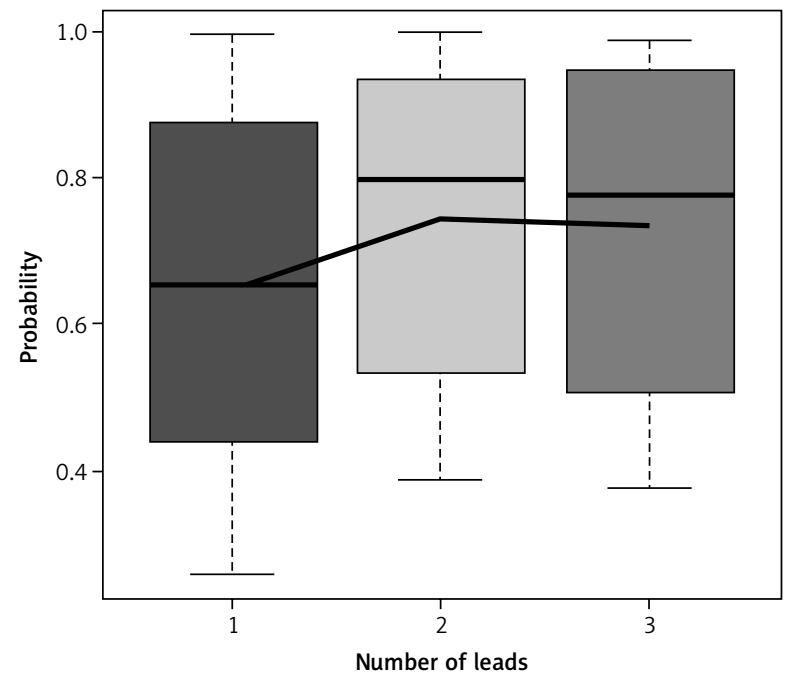

Figure 1. Increasing chance of developing LDIE due to a larger number of endocardial leads

- A longer time interval from the last procedure prior to TLE: 1 month more after the last procedure prior to TLE increased the probability of LDIE by about $1.5 \%$ (Figure 3).

- Among clinical factors: fever and shivering increased the probability of LDIE by 5.8 times, lung infections increased the probability of LDIE by 3.5 times, and elevated CRP increased the probability of LDIE by $0.8 \%$ for one unit increase in CRP.

\section{Discussion}

The simplest and most frequently used classification of infections in patients with PM, ICD and CRT devices includes generator pocket infection with such symptoms as pain, redness, local swelling, sometimes skin erosion in the vicinity of the generator, and generalised infection such as lead-dependent infective endocarditis $[3,6,7]$. However, it is not easy to classify patients according to this scheme. Problems most frequently arise from the impossibility of excluding infection spread in cases of local inflammatory process. A thorough clinical evaluation often results in reclassifying the patients from the PI to the endocarditis group. In the present study the relationship between pocket infection and lead-dependent infective endocarditis was detected in 257 patients, i.e. in $62.1 \%$ of subjects with LDIE and $41.5 \%$ of all subjects with infectious complications. The few papers dealing with LDIE as a separate disease entity demonstrated the concomitant presence of the two types of infections in $46 \%$ to $70 \%$ of patients with CDI [8, 9]. In the present study, the patients with initially diagnosed pocket infection were thoroughly evaluated for the presence of LDIE according to the current classification of CDI, taking into account a smooth progression of the lo-

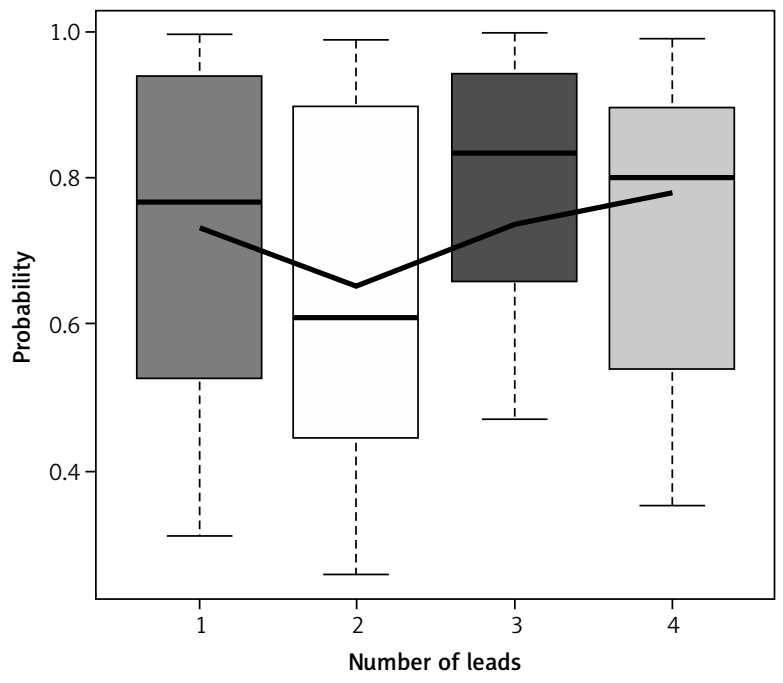

Figure 2. Increasing chance of developing LDIE due to a larger number of pacemaker procedures

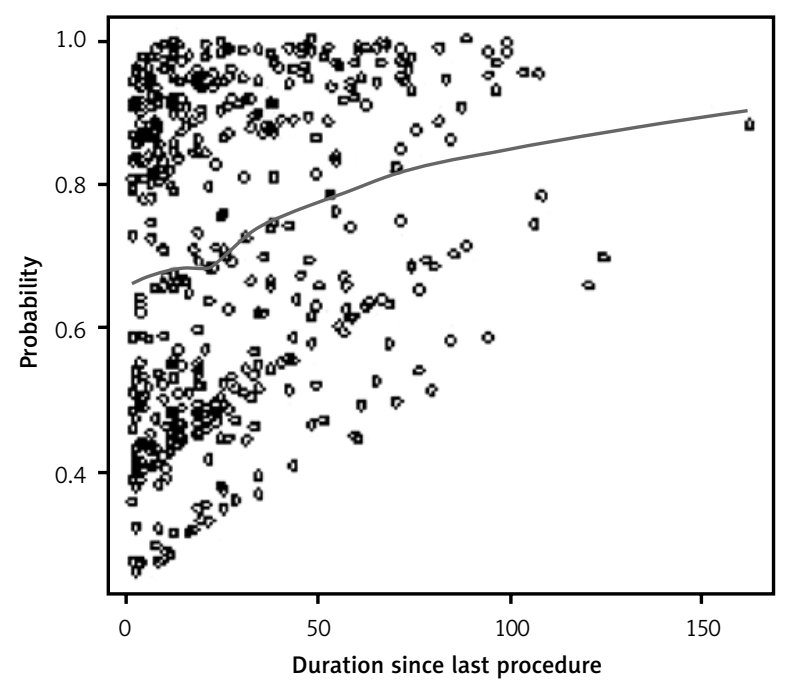

Figure 3. Increasing chance of developing LDIE due to a longer time interval from the last pacemaker procedure

cal process into a generalised severe infection [10, 11]. Initial analysis of risk factors for developing LDIE was a very important part of the evaluation process. The present study demonstrated that patients with LDIE were younger subjects with infectious complications, not differing from those with pocket infection with respect to the presence of the commonest concomitant diseases and possible complications of chronic antiplatelet or anticoagulation therapy. The results of the few studies identifying risk factors for the development of LDIE and PI (10-88 cases of isolated LDIE) are contradictory. In some studies patients with LDIE were younger than in the remaining ones. Similarly, some studies confirmed the more frequent occurrence of diabetes mellitus, chronic renal failure, heart 
failure and lower LVEF in patients with LDIE than in subjects with PI, but other studies did not show this relationship [8, 9, 12-14]. Comparative analysis of procedure-related factors for the development of infection provided conflicting results. Some studies confirmed the effect of a larger number of preceding procedures and pocket haematoma on the development of local infection [15]. Other reports revealed a more frequent development of LDIE in over 1 year and the presence of isolated PI earlier after implantation [9]. However, other studies did not confirm this finding [14]. In the present study analysis of a large group of patients with infectious complications showed an important role of procedure-related risk factors for the development of LDIE as compared with PI. They were as follows: a larger number of endocardial leads, more frequent lead loops, longer time interval from the preceding procedure, and more frequent abrasions of endocardial leads. The presence of these factors is closely associated with the development of abrasion. It was first described by Prof. Kutarski in 2009 [16]. Abrasion refers to biodegradation of the outer silicone insulation of endocardial leads as a result of friction between the lead and intracardiac structures or between leads, and the above-mentioned procedure-related risk factors increase the probability of abrasion. Thorough inspection and microscopic studies of transvenously removed leads have confirmed the relationship between abrasion and a larger number of leads, longer time interval from the preceding procedure as compared with PI, more frequent lead loops, and finally the development of LDIE $[17,18]$. Undoubtedly, abrasion favours colonisation by bacterial pathogens, in this way becoming a probable new mechanism for the development of LDIE, in which the presence of pocket infection is not a sine qua non condition. At this stage LDIE and PI can be regarded as separate disease entities, with LDIE developing insidiously and being undetected for many years. Apart from the initial assessment of risk factors and possible CDI it is very important to evaluate the clinical spread of infection. In the present study the most severe clinical symptoms were found in patients with LDIE, who significantly more frequently developed fever, shivering, and recurrent lung infections. Fever and shivering in the present study were the main clinical symptoms of LDIE, found in $55.1 \%$ of patients (as compared with $14.3 \%$ of patients with PI). These findings are compatible with the results of observational studies in small populations (155 patients altogether) in which fever was detected in $51-80 \%$ of subjects $[6,19,20]$. In turn in a multicentre analysis of 177 subjects, $81 \%$ with LDIE had fever and shivering [21]. It appears that despite non-characteristic symptoms, their severity most frequently correlates positively with infection spread. Multivariate analysis in the present study confirmed that the presence of fever and shivering increased the probability of LDIE by 5.8 times. Lung infection is another important, seemingly nonspecific clinical symptom. Recurrent lower respiratory tract infections in combination with the higher pulmonary artery systolic pressure in patients with LDIE should probably be regarded as a marker of pulmonary embolism, a major Duke criterion. Pulmonary manifestations of LDIE have been rarely considered as a symptom of LDIE that is useful in the assessment of the spread of infection. Generally, pulmonary embolism was regarded as a complication of TLE rather than a diagnostic factor, so CT angiography was rarely used to detect this severe complication. Meanwhile, the incidence of septic pulmonary embolism as a clinical presentation of LDIE has been found to be 33\% in single reports, and the very presence of pulmonary symptoms correlated positively with lead-dependent vegetations [12, 22 ]. In the present study lower respiratory tract infections were detected in $24.9 \%$ of patients with LDIE as compared with only $3.1 \%$ of patients with isolated PI ( $p=0.0001)$, Multivariate analysis also confirmed the significance of lung infections, which increased the probability of LDIE by more than three times. Therefore, fever and recurrent lung infections in patients with PMs, especially with accompanying PI, should prompt a search for LDIE.

In the present study, inflammatory markers were analysed in order to assess the spread of infection. The ESR, levels of CRP, and procalcitonin were markedly higher in patients with LDIE than those with isolated PI. What is interesting was that there was no rise in $\mathrm{WBC}$, which was observed in all types of infections. Furthermore, there was a significantly positive correlation between elevated CRP and the diagnosis of LDIE. Multivariate analysis demonstrated an increased probability of LDIE of $0.8 \%$ for one unit increase in CRP. Evidence from available studies on laboratory parameters in various types of infections is scarce. One study showed significantly higher ESR and CRP in generalised infection as compared with PI; however, WBC was significantly higher both in LDIE and PI [9]. Another study that analysed LDIE (in $48 \%$ with concomitant PI) demonstrated increased WBC and ESR in 59\% of patients; however, the investigators did not differentiate LDIE from LDIE + PI [6]. A similar analysis of 34 cases of CDI, including 15\% with LDIE and 15\% with LDIE + PI showed average levels of WBC 8320/ $\mu 1$ in the presence of elevated ESR and CRP $(20 \mathrm{~mm} / 1 \mathrm{~h}$ and $18 \mathrm{mg} / \mathrm{l}$ on average, respectively) without differentiation between the types of infection [15].

Another parameter that differentiates local infection from lead-dependent infective endocarditis is positive blood culture, a major Duke criterion for the diagnosis of LDIE, and positive culture of lead segments, a criterion whose role in the spread of infection is not completely confirmed. In the present study the pathogens in blood were found in $48.4 \%$ of patients with LDIE. The low rates of positive blood 
cultures should be ascribed to early antibiotic therapy used in $76.3 \%$. Available studies confirmed positive blood cultures in $68-92 \%$ of patients, but in small populations consisting of $44-66$ subjects $[6,19,20]$. In the present study positive cultures of lead segments were found in $46.4 \%$ of patients with LDIE and only in $1.5 \%$ of patients with PI. According to the current European guidelines on the prevention, diagnosis, and treatment of infective endocarditis, positive cultures of lead segments can be regarded as a diagnostic criterion of LDIE only when the leads were removed, avoiding bacterial contamination from the infected generator pocket [5]. In the present study positive cultures of explanted lead segments were found significantly more frequently in patients with LDIE, and this concerned $62 \%$ of TLE procedures through the infected pocket. However, it seems important to take into account all clinical data as well as careful inspection of transvenously explanted leads (frequent purulent discharge from the lead and sample collection at the proximal cutoff end of the lead). Because of the precise sampling procedure in the present study, positive cultures of explanted leads were considered as an important sign of infection spread. A recent report of 471 patients with infectious complications confirmed this approach [23].

Echocardiography, especially transoesophageal, is indispensable for the evaluation of the spread of infection. The most important diagnostic sign of LDIE is the presence of vegetations, which were detected in $67.6 \%$ of patients with LDIE. Recent studies confirm the important role of echocardiography, especially TEE, together with intracardiac examinations in the evaluation of the spread of infection. In an analysis of 154 cases with CDI $40 \%$ of patients with initial pocket infection had vegetations [8]. In turn, the absence of vegetations in $32.4 \%$ of patients with confirmed LDIE was probably a result of the dynamic course of LDIE with the formation, breakdown, and displacement of vegetations to the pulmonary circulation [24]. This was confirmed by the higher rate of lung infections and higher pulmonary artery systolic pressures in patients with LDIE.

The retrospective nature of the analysis of clinical data is the basic limitation. It is likely that more patients presented clinical symptoms that could be important in evaluation of extensity of infectious process.

\section{Conclusions}

Lead-dependent infective endocarditis frequently coexists with pocket infection and is regarded as a form of the infective process extending from the infected pocket along the leads to the endocardium. The presence of LDIEs without accompanying PI requires consideration of two different pathogenetic mechanisms. Analysis of potential risk factors for the development of each type of infection in the present study showed that LDIE is significantly more frequently associated with the presence of abrasion of endocardial leads, a new, still poorly understood pathogenetic phenomenon. This phenomenon in turn is closely correlated with the presence of other procedure-related risk factors. Clinically, LDIE is most frequently characterised by a more severe course than PI, developing with fever, shivering, and recurrent lung infections. Multivariate analysis confirmed the significance of the symptoms. Despite low specificity of laboratory tests, when differentiating the two types of infections one should take into account higher levels of inflammatory markers (CRP, ESR, procalcitonin) in patients with LDIE than in those with PI, especially increased CRP in the course of LDIE, which was confirmed in multivariate analysis. No rise in WBC is also a significant finding in all types of lead-dependent infections. Analysis of blood cultures is frequently unreliable because of early antibiotic therapy. In the present study, positive cultures of explanted leads (together with careful inspection of the leads and all clinical manifestations) played an important role in the assessment of the spread of infection. Transoesophageal echocardiography is a very important tool to help differentiate LDIE from PI. TEE should be routinely used to diagnose a variety of lead-dependent infections.

\section{Conflict of interest}

The authors declare no conflict of interest.

\section{References}

1. Voigt A, Shalaby A, Saba S. Continued rise in rates of cardiovascular implantable electronic device infections in the United States: temporal trends and causative insights. Pacing Clin Electrophysiol 2010; 33: 414-9.

2. Cabell $\mathrm{CH}$, Heidenreich $\mathrm{PA}, \mathrm{Chu} \mathrm{VH}$, et al. Increasing rates of cardiac device infections among Medicare beneficiaries: 1990-1999. Am Heart J 2004; 147: 582-6.

3. Sohail MR, Uslan DZ, Khan AH, et al. Management and outcome of permanent pacemaker and implantable cardioverter-defibrillator infections. J Am Coll Cardiol 2007; 49: 1851-9.

4. Greenspon AJ, Patel JD, Lau E, et al. 16-Year trends in the infection burden for pacemakers and implantable cardioverter-defibrillators in the United States 1993 to 2008. J Am Coll Cardiol 2011; 58: 1001-6.

5. Habib G, Hoen B, Tornos P, et al. ESC Committee for Practice Guidelines. Guidelines on the prevention, diagnosis, and treatment of infective endocarditis (new version 2009): the Task Force on the Prevention, Diagnosis, and Treatment of Infective Endocarditis of the European Society of Cardiology (ESC). Endorsed by the European Society of Clinical Microbiology and Infectious Diseases (ESCMID) and the International Society of Chemotherapy (ISC) for Infection and Cancer. Eur Heart J 2009; 30: 2369-413.

6. Sohail MR, Uslan DZ, Khan AH, et al Infective endocarditis complicating permanent pacemaker and implantable cardioverter defibrillator infection. Mayo Clin Proc 2008; 83: 46-53. 
7. Bongiorni MG, Marinskis G, Lip GY, et al. How European centres diagnose, treat, and prevent CIED infections: results of an European Heart Rhythm Association survey. Europace 2012; 14: 1666-9.

8. Golzio PG, Fanelli AL, Vinci M, et al. Lead vegetations in patients with local and systemic cardiac device infections: prevalence, risk factors, and therapeutic effects. Europace 2013; 15: 89-100.

9. Tarakji KG, Chan EJ, Cantillon DJ, et al. Cardiac implantable electronic device infections: presentation, management, and patient outcomes. Heart Rhythm 2010; 7: 1043-7.

10. Clinical cardiac pacing, defibrillation, and resynchronization therapy. Ellenbogen KA, Kay GN, Lau CP, Wilkoff BL (eds.). Saunders Elsevier, Philadelphia 2007; 912-30.

11. Durante-Mangoni E, Mattucci I, Agrusta F, et al. Current trends in the management of cardiac implantable electronic device (CIED) infections. Intern Emerg Med 2013; 8: 465-76.

12. Deharo JC, Quatre A, Mancini J, et al. Long-term outcomes following infection of cardiac implantable electronic devices: a prospective matched cohort study. Heart 2012; 98: 724-9.

13. Viganego F, O'Donoghue S, Eldadah Z, et al. Effect of early diagnosis and treatment with percutaneous lead extraction on survival in patients with cardiac device infections. Am J Cardiol 2012; 109: 1466-71.

14. Nery PB, Fernandes R, Nair GM, et al. Device-related infection among patients with pacemakers and implantable defibrillators: incidence, risk factors, and consequences. J Cardiovasc Electrophysiol 2010; 21: 786-90.

15. Ipek EG, Guray U, Demirkan B, et al. Infections of implantable cardiac rhythm devices: predisposing factors and outcome. Acta Cardiol 2012; 67: 303-10.

16. Kutarski A, Małecka B. Przetarcie silikonowych izolacji elektrod wewnątrzsercowych - nowo odkryte zjawisko w elektroterapii: obserwacje własne. Folia Cardiol Exc 2009; 4: 126-31.

17. Kołodzińska A, Kutarski A, Kozłowska M, et al. Biodegradation of the outer silicone insulation of endocardial leads. Circ Arrhythm Electrophysiol 2013; 6: 279-86.

18. Chatelain P, Adamec R, Cox JN. Morphological changes in human myocardium during permanent pacing. Virchows Arch (Pathol Anat) 1985; 407: 43-57.

19. Massoure PL, Reuter S, Lafitte $S$, et al. Pacemaker endocarditis: clinical features and management of 60 consecutive cases. Pacing Clin Electrophysiol 2007; 30: 12-9.

20. Sarrazin JF, Philippon F, Tessier M, et al. Usefulness of fluorine-18 positron emission tomography/computed tomography for identification of cardiovascular implantable electronic device infections. J Am Coll Cardiol 2012; 59: 1616-25.

21. Athan E, Chu VH, Tattevin P, et al. Clinical characteristics and outcome of infective endocarditis involving implantable cardiac devices. JAMA 2012; 307: 1727-35.

22. Schmitt CG, Ellringmann U, Köhler F. Experiences with transvenously implanted pacemaker electrodes with special remarks on the treatment of leads out of function. Z Kardiol 1977; 66: 447-53.

23. Bongiorni MG, Tascini C, Tagliaferri E, et al. Microbiology of cardiac implantable electronic device infections. Europace 2012; 14: 1334-9.

24. Greenspon AJ, Rhim ES, Mark G, et al. Lead-associated endocarditis: the important role of methicillin-resistant
Staphylococcus aureus. Pacing Clin Electrophysiol 2008; 31: 548-53.

\section{Address for correspondence:}

Prof. Anna Polewczyk

Department of Medicine and Health Sciences

Faculty of Health Sciences

Jan Kochanowski University

ul. IX Wieków Kielc 19, 25-317 Kielce, Poland

Phone: +48 $413671508,+48600024074$

E-mail: AnnaPolewczyk@wp.pl 